\title{
The Impact of Long-Term Athlete Development-based Exercise Towards Physical Ability and Academic Achievement
}

\author{
SULISTIYONO $^{1,2 *}$, SUGIYANTO ${ }^{2}$, AGUS KRISTIYANTO $^{2}$, SAPTA KUNTA PURNAMA ${ }^{2}$, \\ JUMADIL SAPUTRA $^{3 *}$, SISWANTOYO ${ }^{1}$, NAWAN PRIMASONI ${ }^{1}$ \\ ${ }^{1}$ Department of Sport Science \\ Faculty of Sport Science \\ Universitas Negeri Yogyakarta \\ Sleman, Daerah Istimewa Yogyakarta 55281 \\ INDONESIA \\ ${ }^{2}$ Department of Sport Science \\ Faculty of Sport Science \\ Universitas Sebelas Maret \\ Surakarta, Jawa Tengah 57126 \\ INDONESIA \\ ${ }^{3}$ Department of Economics \\ Faculty of Business, Economics and Social Development \\ Universiti Malaysia Terengganu \\ 21030 Kuala Nerus, Terengganu \\ MALAYSIA
}

\begin{abstract}
High training intensity, volume, and academic demands have negatively affected young athletes' academic achievements. This study is written to determine the differences in the effects of long-term athlete development-based football training on football players' physical abilities and academic achievements aged 10 and 12 years. Forty-four young football players were involved in this study divided into two age groups of 10 (n $=21)$ and $12(\mathrm{n}=23)$. Before and after the six-month and one-year treatment, physical abilities, consisting of 30 $\mathrm{m}$ sprint ability and leg muscle explosive power, were measured using a vertical jump test and aerobic endurance with a multistage fitness test (MFT). In contrast, academic achievement was measured by documenting the scores of mathematics, language, science, social sciences in the report book. The results showed that the long term athlete development-football training model impacted physical abilities but did not affect academic achievements. There was no significant difference between groups of ages 10 and 12. Longterm athlete development-based football training can develop physical abilities and support young football players to complete academic activities.
\end{abstract}

Key-Words: - academic achievement, football, physical ability, long term athlete development, and training

Received: February 8, 2021. Revised: July 1, 2021. Accepted: July 5, 2021. Published: July 10, 2021.

\section{Introduction}

The number of children and adolescents participating in organised sports or recreation has increased over the past 20 years. Sports activities can be classified for achievement, education, or recreation, and health purposes. Sports training has benefits such as improving competencies and skills in a sport [1], but sports training is also expected to support personality development [2] and character [3], [4], and improve health status [5]. Exercise can prevent chronic diseases, achieve awareness of physical activity, and motivate individuals to continue to engage in a healthy lifestyle [6]. Achievement in sports training is a noble goal, but sometimes that in young athletes results in injury, negative behaviour, and failure to attend formal education).

Various strategies and sports policies are selected and carried out by various countries with their disadvantages and advantages. Models of coaching and training for young athletes include the Developmental Model of Sports Participation (DMSP), Long Term Athlete Development (LTAD), Youth Positive Development (YPD) [7], and an 
early specialisation exercise model. The implementation of sports policy at the technical stage in the field may not be easily observed because it is a process of activities and exercises with certain principles carried out for a long time with orientation, effect, risk, and factors that influence many complicated things. The results of research on a development model of sports training implemented in the UK on the swimming sports branch shows that athletes age 13-15 years who do more than two sports can compete at the national level at the age of 16-18 compared to those who do early specialisation or one sports branch.

Strachan, MacDonald and Côté [8] stated that the program sport connect and respect (SCORE) is a physical activity and physical education designed to develop athletes' attitudes and behaviours. Another learning model is sports united to promote education and recreation (SUPER) [9] to develop life skills. The long term athlete development is a model of planned, structured, and progressive training to achieve career success in sports at the right time [10] and to have healthy lifestyles, attitudes, positive behaviours, and awareness of the importance of formal education as the provision after a sports career [11].

The aim of optimal achievement in practising sports and reaching the level of elite athletes in some cases results in excessive training programs. Exercises are carried out with high volume and intensity. Early specialisation is conducted mainly in gymnastics, swimming, and football, where the athletes still study at the elementary or junior high school level [10],[12]. Sports training experts state that specialised training in the sports branch should be taken at the age of 12-15 years, and the exercise can start at the age of 6-9 [13]-[15]. Myer et al., [10] stated that excessive exercise risks and too often competition at a young age include injury, fatigue, and quitting exercising. Arkaev and Suchilin [16] researched the branches of gymnastics, swimming, diving, and rhythmic gymnastics. The results showed that a high training load and academic demands were two factors that caused chronic stress on young athletes [15],[17],[18]. Other studies stated that physical activities and physical fitness identical to sports training could improve young athletes' cognitive abilities and academic achievements [19]. Also, academic achievement improvement is influenced by the degree of health and self-esteem [20].

A significant relationship exists between fitness and academic achievement, even though its nature is unknown [21]. Physical activities with specific models should be promoted, supported by the government's political decisions, and implemented in the educational process [22]. Research that tries to determine the relationship between physical activity, physical fitness and academic achievement is still cross-sectional and short-term. In contrast, studies related to physical abilities are still associated with exercise intervention. Research on the effects of sports exercise on physical abilities, and academic achievements in young athletes have not conducted over a long time, particularly sports exercises specifically designed based on certain models, policies, and training strategies.

Sports achievement for an athlete is important, but formal education for a post-career life is also essential. This research was conducted to discover the effects of football training, which implements a long-term athlete development on physical abilities and academic achievement for footballers aged 10 and 12. The influence of structured and organised sports training on young athletes must be appropriately managed so that sports coaching to produce a prosperous human being can be achieved. The study results are crucial for parents, administrators, football coaches, and sports policymakers responsible for young athletes' welfare and future.

\section{Material and Method}

This study uses experimental research on a football training model, which was applied within a year. This research was carried out in Selabora football school in Sleman Regency, which provides education and training services for young football players. Player's parents gave information about the objectives, methods, and risks in the study. A written agreement made between the researcher, the athlete's parents, and the selected 44 young players aged 9-12 who took formal education from elementary to junior high school levels. Forty-four young football players divided into two treatment groups of age $10(n=21)$ and $12(n=23)$.

The active sample participated in the training with a long-term athlete development model. The policy of developing elite athletes with the model in the 'learn to train' phase (age 9-12) has the following guidelines: 1) basic skill development as a basis for further skill development, 2) training process carried out in a pleasant atmosphere, 3) safety, 4) introduction of ethical and straightforward rules, 5) instructions given formally but limited, 6) development of agility, balance, and coordination, 7) strength training using one's limbs, 8) participation in physical exercises or activities in other sports [23]. The exercises were carried out 
with a frequency of $3 \mathrm{x}$ a week with 120 minutes for each training session. The daily training plan contains three main activities, namely: 1) development of physical abilities, agility, coordination, and strength in 15-20 minutes, 2) football basic skill drills in 20-25 minutes, 3) modified games in 15-25 minutes, and 4) 7 vs. 7 play with a field area of $60 \times 40 \mathrm{~m}$ for 20 minutes. The players join the competition at the district and province levels with a frequency of $6 \mathrm{x}$ competition events.

The measurements of physical abilities and academic achievements were carried out before and after six-month and one-year treatment to determine the difference in football training effects with the long-term athlete development model. The physical ability consisting of $30 \mathrm{~m}$ sprint ability, leg muscle explosive power, and aerobic endurance have measured by field practice tests with a $30 \mathrm{~m}$ sprint test, vertical jump test, and multistage fitness test. Meanwhile, the academic achievement data has collected by documenting the scores of mathematics, language, natural sciences, and social sciences in the school report. The measurement process was carried out in the afternoon from 15.00 to 17.30 Western Indonesian Time at the sports laboratory in the Faculty of Sports Science, Yogyakarta State University.

The first measurement (pre-test) was carried out in January 2019, close to the time the players received the second-semester school report of the 2018/2019 academic year. The second measurement (mid-test) was carried out in July 2019, which was close to when the players received the semester I school report of the 2019/2020 academic year. The 3rd measurement (post-test) was conducted in January 2020 in which the players almost received the second-semester school report of 2019/2020 academic year. The data were analysed using a t-test to determine the training model's effects on physical abilities and academic achievements in each experimental group. Simultaneously, the researcher used the ANCOVA test analysis to determine the difference in impact between the two experimental groups. The level of significance was $p<0.05$ with the help of the SPSS 20 program.

\section{Results and Discussion}

\subsection{Results}

The selected sample participated in the treatment, with an average attendance percentage of $85 \%$ per month. Four players from the age 10 group and two players from the age 10 group could not continue the treatment because they stopped exercising. Forty-four players completed the treatment in the study ( $\mathrm{n}=21$, age: 10 and $\mathrm{n}=23$, age: 12$)$. None of the participants suffered injuries related to tests or training during the 12-month treatment period. The initial profile of young football players as the study sample, as seen in Table 1.

Table 1. Sample Characteristics on Age 10 and 12 Experimental Groups

\begin{tabular}{lcccc}
\hline \multirow{2}{*}{ Profile } & \multicolumn{2}{c}{$\begin{array}{c}\text { Age Group of 10 } \\
(\mathrm{n}=21)\end{array}$} & \multicolumn{2}{c}{$\begin{array}{c}\text { Age Group of 12 } \\
(\mathrm{n}=23)\end{array}$} \\
\cline { 2 - 5 } & Mean & S.D & Mean & S.D \\
\hline Age & 9.45 & 0.45 & 11.32 & 0.44 \\
Height & 132.86 & 5.03 & 136.21 & 5.27 \\
Weight & 30.29 & 7.73 & 33.52 & 7.17 \\
\hline
\end{tabular}

Table 2 shows a summary of the measurement data on young players' physical abilities and academic achievements who became the study sample divided into two treatment groups: age 10 and 12 . The physical ability consists of a $30 \mathrm{~m}$ sprint speed, explosive power leg muscle, and aerobic endurance. In contrast, academic achievement consists of four subjects: Mathematics, Indonesian Language, Natural Sciences, and Social Sciences. The pre-test presented the measurement results before the treatment; the mid-test shows the measurement results after six-month treatment, and the post-test provides the measurement results after the one-year treatment. The physical abilities changes are analysed by considering the mean differences at different measurement times, as seen in Table 2.

Table 2. Physical Ability and Academic

Achievement of the Age 10 and 12 Group

\begin{tabular}{|l|c|c|c|c|c|c|}
\hline \multirow{2}{*}{ Ability } & \multicolumn{6}{|c|}{ Age Group $10(\mathrm{n}=21)$} \\
\cline { 2 - 7 } & \multicolumn{2}{|c|}{ Pre-Test } & \multicolumn{2}{c|}{ Mid Test } & \multicolumn{2}{c|}{ Post-Test } \\
\cline { 2 - 7 } & Mean & SD & Mean & SD & Mean & SD \\
\hline $\begin{array}{l}\text { Speed of } \\
(30 \mathrm{~m})\end{array}$ & 5.78 & 0.22 & 5.56 & 0.24 & 5.28 & 0.3 \\
\hline $\begin{array}{l}\text { Leg } \\
\text { Muscle } \\
\text { Explosive } \\
\text { Power }\end{array}$ & 28.19 & 4.66 & 30.48 & 4.85 & 32.95 & 4.55 \\
\hline $\begin{array}{l}\text { Aerobic } \\
\text { Endurance }\end{array}$ & 30.22 & 5.46 & 32.91 & 6.33 & 35.31 & 6.63 \\
\hline $\begin{array}{l}\text { Academic } \\
\text { Achieveme } \\
\text { nt (Total) }\end{array}$ & 80.71 & 7.93 & 82.05 & 7.36 & 79.64 & 6.11 \\
\hline $\begin{array}{l}\text { Indonesian } \\
\text { Language }\end{array}$ & 83.21 & 7.42 & 82.66 & 7.26 & 82.33 & 5.98 \\
\hline $\begin{array}{l}\text { Mathemati } \\
\text { cs }\end{array}$ & 78.27 & 10.0 & 81.76 & 8.76 & 76.86 & 8.14 \\
\hline
\end{tabular}




\begin{tabular}{|l|c|c|c|c|c|c|}
\hline \multirow{2}{*}{ Ability } & \multicolumn{6}{|c|}{ Age Group 12 (n=23) } \\
\cline { 2 - 7 } & \multicolumn{2}{|c|}{ Pre-Test } & \multicolumn{2}{c|}{ Mid Test } & \multicolumn{2}{c|}{ Post-Test } \\
\cline { 2 - 7 } & Mean & SD & Mean & SD & Mean & SD \\
\hline $\begin{array}{l}\text { Speed of } \\
(30 \mathrm{~m})\end{array}$ & 5.88 & 0.41 & 5.4 & 0.36 & 5.21 & 0.34 \\
\hline $\begin{array}{l}\text { Leg } \\
\text { Muscle } \\
\text { Explosive } \\
\text { Power }\end{array}$ & 30.96 & 3.9 & 33.43 & 4.36 & 33.37 & 5.85 \\
\hline $\begin{array}{l}\text { Aerobic } \\
\text { Endurance }\end{array}$ & 29.37 & 5.25 & 34.06 & 5.37 & 36.17 & 5.59 \\
\hline $\begin{array}{l}\text { Academic } \\
\text { Achieveme } \\
\text { nt (Total) }\end{array}$ & 80.89 & 6.74 & 81.08 & 6.74 & 80.25 & 6.88 \\
\hline $\begin{array}{l}\text { Indonesian } \\
\text { Language }\end{array}$ & 83.09 & 7.61 & 81.74 & 6.48 & 80.04 & 7.09 \\
\hline $\begin{array}{l}\text { Mathemati } \\
\text { cs }\end{array}$ & 79.78 & 9 & 80.96 & 8.47 & 79.7 & 8.02 \\
\hline
\end{tabular}

Tables 3 and 4 present the results of the paired ttest in the age groups of 10 and 12 years to determine the effect of training on physical abilities and academic achievement. The difference in the average value before and after six month-treatment; before and after twelve-month treatment; and the sig scores (2-tailed) shows that the long-term athlete development-based training has a significant effect on physical abilities, but it does not have a significant effect on academic achievement. The significance test results can be seen in the Sig. (2tailed) table; if the value of the paired t-test is less than 0.05 , it means that the exercise has a significant effect, but if the value of the paired t-test is greater than 0.05 , it indicates that the exercise does not affect the variable.

Based on the description in Tables 3 and 4, there is an increase and change in scores on the overall physical ability after a six-month treatment of $30 \mathrm{~m}$ sprint speed, leg muscle explosive power, and aerobic endurance. Also, the difference in average scores after 12-month treatment is more significant. Long-term athlete development-based exercises implemented in the two experimental groups can effectively improve physical abilities. After the treatment changed the sample's academic achievement scores, but it was not significant, even a decline occurred in the two treatment groups after the 12-month treatment. Based on Tables 3 and 4, the results of the paired t-test show that long-term athlete development-based exercise does not affect the players' academic achievement.
Table 3. Statistical Test Results with Paired Samples Test for Age 10 Group

\begin{tabular}{|c|c|c|c|c|}
\hline \multirow[b]{2}{*}{ Variable(s) } & \multicolumn{3}{|c|}{ Paired Differences } & \multirow[b]{2}{*}{$\mathrm{t}$} \\
\hline & Mean & SD & $\begin{array}{c}\text { Std. } \\
\text { Error } \\
\text { Mean }\end{array}$ & \\
\hline $\begin{array}{l}\text { Speed (T0) - } \\
\text { Speed (T1) }\end{array}$ & 0.22 & 0.21 & 0.045 & $4.8^{* * *}$ \\
\hline $\begin{array}{l}\text { Speed (T1) - } \\
\text { Speed (T2) }\end{array}$ & 0.50 & 0.25 & 0.054 & $9.19^{* * *}$ \\
\hline $\begin{array}{l}\text { Explosive } \\
\text { Power (T0) - } \\
\text { Explosive } \\
\text { Power (T1) } \\
\end{array}$ & -2.29 & 3.04 & 0.662 & $-3.45^{* * *}$ \\
\hline $\begin{array}{l}\text { Explosive } \\
\text { Power (T1) - } \\
\text { Explosive } \\
\text { Power (T2) }\end{array}$ & -4.76 & 4.95 & 1.080 & $-4.41^{* * *}$ \\
\hline $\begin{array}{l}\text { Aerobic } \\
\text { Endurance } \\
\text { (T0) - Aerobic } \\
\text { Endurance } \\
\text { (T1) }\end{array}$ & -2.70 & 3.64 & 0.795 & $-3.39^{* * *}$ \\
\hline $\begin{array}{l}\text { Aerobic } \\
\text { Endurance } \\
\text { (T1) - Aerobic } \\
\text { Endurance } \\
\text { (T2) }\end{array}$ & -5.10 & 4.47 & 0.976 & $-5.22^{* * *}$ \\
\hline $\begin{array}{l}\text { Academic } \\
\text { Achievement } \\
\text { Total (T0) - } \\
\text { Academic } \\
\text { Achievement } \\
\text { Total (T1) }\end{array}$ & -1.33 & 3.42 & 0.747 & $-1.79^{*}$ \\
\hline $\begin{array}{l}\text { Academic } \\
\text { Achievement } \\
\text { Total (T1) - } \\
\text { Academic } \\
\text { Achievement } \\
\text { Total (T2) } \\
\end{array}$ & 1.07 & 5.26 & 1.147 & 0.93 \\
\hline
\end{tabular}

Note: $* * *, * * *$ is significant at the level $1 \%, 5 \%$ and $10 \%$ with df. 20

Table 4. Statistical Test Results with Paired Samples Test for Age 12 Group

\begin{tabular}{|l|c|c|c|c|}
\hline \multirow{2}{*}{} & \multicolumn{2}{|c|}{ Paired Differences } & \multirow{2}{*}{$\mathrm{t}$} \\
\cline { 2 - 4 } & Mean & SD & $\begin{array}{c}\text { Std. Error } \\
\text { Mean }\end{array}$ & \\
\hline $\begin{array}{l}\text { Speed (T0) - } \\
\text { Speed (T1) }\end{array}$ & 0.42 & 0.18 & 0.038 & $11.11^{* * *}$ \\
\hline $\begin{array}{l}\text { Speed (T1) - } \\
\text { Speed (T2) }\end{array}$ & 0.66 & 0.44 & 0.092 & $7.20^{* * * *}$ \\
\hline $\begin{array}{l}\text { Explosive } \\
\text { Power (T0) - } \\
\text { Explosive } \\
\text { Power (T1) }\end{array}$ & -2.48 & 2.13 & 0.444 & $-5.58^{* * *}$ \\
\hline
\end{tabular}




\begin{tabular}{|l|c|c|c|c|}
$\begin{array}{l}\text { Explosive } \\
\text { Power (T1) - } \\
\text { Explosive } \\
\text { Power (T2) }\end{array}$ & -3.84 & 3.98 & 0.83 & $-4.62^{* * *}$ \\
\hline $\begin{array}{l}\text { Aerobic } \\
\text { Endurance } \\
\text { (T0) - Aerobic } \\
\text { Endurance } \\
\text { (T1) }\end{array}$ & -3.76 & 4.39 & 0.915 & $-4.11^{* * *}$ \\
\hline $\begin{array}{l}\text { Aerobic } \\
\text { Endurance } \\
\text { (T1) - Aerobic } \\
\text { Endurance } \\
\text { (T2) }\end{array}$ & -6.00 & 4.08 & 0.851 & $-7.05^{* * *}$ \\
\hline $\begin{array}{l}\text { Academic } \\
\text { Achievement } \\
\text { Total (T0) - } \\
\text { Academic } \\
\text { Achievement } \\
\text { Total (T1) }\end{array}$ & -0.24 & 3.07 & 0.64 & -0.37 \\
\hline $\begin{array}{l}\text { Academic } \\
\text { Achievement } \\
\text { Total (T1) - } \\
\text { Academic } \\
\text { Achievement } \\
\text { Total (T2) }\end{array}$ & 0.66 & 5.00 & 1.043 & 0.64 \\
\hline Not * & & & & \\
\hline
\end{tabular}

Note: ***, **, * is significant at the level $1 \%, 5 \%$ and $10 \%$ with df. 20

The data were analysed using the ANCOVA Test with SPSS-20 to determine the differences in the two treatment groups' effects on physical abilities and academic achievements. The analysis results show no difference in the effects between the groups on physical abilities and academic achievement. It is based on the result of the significance test using the ANCOVA Test, where the Sig. Value is greater than 0.05 . The differences in effects between the groups occurred in the sprint speed component after a 6-month treatment where the Sig. Score is 0.002, which is less than 0.05 (the result is in Table 5). The exercise model has a significant effect on physical abilities. Still, it does not affect academic achievements, and there is no significant difference in effects between the age of 10 and 12 groups (Table 5).
Table 5. Statistical Test Results with the UnivariateANCOVA Technique

\begin{tabular}{|l|l|c|c|c|c|}
\hline \multicolumn{2}{|c|}{ Result after 6-month treatment } & \multicolumn{2}{c|}{$\begin{array}{c}\text { Result after } \\
\text { 12-month } \\
\text { treatment }\end{array}$} \\
\hline \multicolumn{2}{|c|}{ Parameter } & B & Sig. & B & Sig. \\
\hline $\begin{array}{l}\text { Speed } \\
\text { KU=10 }\end{array}$ & $\begin{array}{l}\text { VS } 12 \\
\text { Th }\end{array}$ & 0.19 & 0.002 & 0.11 & 0.266 \\
\hline $\begin{array}{l}\text { Explosive } \\
\text { Power }\end{array}$ & $\begin{array}{l}\text { KU } 10 \\
\text { VS } 12 \\
\text { Th }\end{array}$ & -0.49 & 0.556 & 0.38 & 0.789 \\
\hline $\begin{array}{l}\text { Aerobic } \\
\text { Endurance }\end{array}$ & $\begin{array}{l}\text { KU=10 } \\
\text { VS } 12 \\
\text { Th }\end{array}$ & -1.26 & 0.28 & -1.08 & 0.388 \\
\hline $\begin{array}{l}\text { Academic } \\
\text { Achievement }\end{array}$ & $\begin{array}{l}\text { KU } 10 \\
\text { VS } 12 \\
\text { Th }\end{array}$ & 1.06 & 0.265 & -0.48 & 0.723 \\
\hline
\end{tabular}

\subsection{Discussion}

Development and coaching of young athletes to compete at an elite level must cover some aspects, one of which is a physical component. Also, athlete development is a very complex process. Performance in sports is based on skills (technical, perceptive, neurocognitive, psycho-social, and physical), which in the right situation are applied in the environment, systems, and opportunities [24]. The complexity of the athlete performance in sports competitions results in the low success percentage for children and adolescents to gain achievement at the elite level. The athlete development paradigm must be holistic, multidimensional, and based on the best training model for each stage of development concerning age, physical factor, maturity, and flexibility.

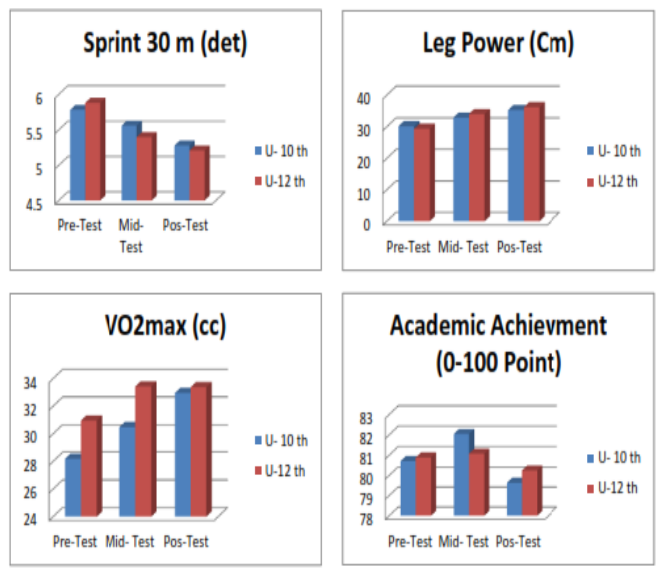

Fig.1. The Comparison of Test Results on Physical Ability and Academic Achievement between Age 
10 and 12 Groups in Pre-Test, Mid-test, and Posttest.

Implementing the long-term athlete development model for 12 months has positively influenced physical development (Figure 1). The effect of organised exercise training on physical abilities is well known. For example, based on a research result [25] on football training effects with small side game and ballless models, both training models are equally effective in improving physiological changes and physical performance during the game. The result of this study is in line with the statement that physical fitness and body composition of 11-year-old football players are better than the those of control group during two seasons of training [26], [27], especially in terms of speed (10 and $30 \mathrm{~m}$ sprints), agility, leg muscle explosive power (countermovement jump), endurance (VO2max), and body fat percentage. High-intensity aerobic training for 30 minutes per session at least once a week during the competition period showed a $15 \%$ increase in aerobic endurance and a $21 \%$ increase in speed with the sprint test after 12-week treatment [28].

Bellistri et al. [29] stated that the physical abilities and technical skills of the 12 Italian national team players age 10 are as follows. Leg muscle explosive power has an average of $0.23 \pm$ SD $0.03 \mathrm{~m}$, and the $30 \mathrm{~m}$ sprint ability is on an average of $5.72 \pm$ SD 0.22s [29]. The comparison of the study results and those of Bellistri et al. [29] showed a difference in physical ability, which is not significant at the age of 10 years; thus, the long-term athlete development model can be claimed effective for the improvement of physical abilities. Also, research conducted by Malina, et al. [30] proved that the physical abilities achieved by the sample due to the treatment to the age 12 group have developed and been ready to compete for the next coaching which is a specialisation of a sports branch. Malina et al. found out the running speed, leg muscle explosive power, and aerobic endurance of athletes who possessed high-level football skills at the age of 14 (see Table 6). Based on the physical ability parameters, the long-term athlete development training model is effective in preparing football players age 10-12 years to achieve optimal performance in the future.
Table 6. Physical Performance of Elite Young Football Players Age 14

\begin{tabular}{|l|c|c|}
\hline \multirow{2}{*}{ Skill-Based Groping } & \multicolumn{2}{c|}{ Intensity } \\
\cline { 2 - 3 } & Highest & High \\
\hline Age (years) & $14.5(0.6)$ & $14.2(0.6)$ \\
\hline Experience (years) & $5.1(1.7)$ & $4.1(1.8)$ \\
\hline Height (cc/kg minute) & 168.6 & 169.6 \\
\hline Weight (kg) & $57.0(9.3)$ & $59.8(9.5)$ \\
\hline Sprint (s) & $4.75(0.23)$ & $4.89(0.27)$ \\
\hline Vertical jump & $30.8(4.9)$ & $30.2(3.9)$ \\
\hline Endurance-run (m) & 2983 & 2394 \\
\hline
\end{tabular}

Sprint involves muscles' functions, which lengthen and shorten, and the upper and lower body movement systems [31]. Sprint ability is highly associated with explosive power [32]. Haugen [33] stated that interval training and weight training could improve the football players' sprint ability. Some researchers recommend training in highintensity aerobic intervals (80-90\% of VO2max), besides the repeated sprints, to improve the ability of repeated sprints in football players [34]. Longterm athlete development-based exercises containing modified games are proven effective in enhancing the sprint ability of players aged 10 and 12. The development of sprint skills in football players can be done through several methods selected by the coaches. Some researchers recommend training in high-intensity aerobic intervals (80-90\% of VO2max), in addition to repeated sprints to improve the ability of repeated sprints in football players [34]. Long-term athlete development-based exercises that contain modification games are proven to increase the sprint ability of players age 10 and 12 years. Several methods selected by the coaches can do the development of sprint skills in football players.

Football players have to perform technical and tactical skills and need skills supported by large explosive power. Actions taken by players with explosive power are likely to be decisive when body fights, winning the ball and preventing the opponents from scoring goals [35]. Research conducted by Cronin, JB, and Hansen, KT (2005) show that players who have faster running skills have higher explosive power, according to this study's results. The training characteristic applied to the research is a play in which players often unconsciously sprint at a distance of $5-15$ or $5-10$ with a high percentage, [36] and do repeated sprint movements which can increase the explosive power [37].

The physical abilities of the age of 10 and 12 groups in aerobic endurance showed that the sample 
had a high fitness level. Football training with a long-term athlete development model with a frequency of $3 x$ a week, high intensity of 30-45 minutes to join several regular competitions has complex physiological and psychological effects. High-intensity football training can be divided into aerobic and anaerobic exercises [36]. High-intensity aerobic training influences cardiovascular enhancement [38], blood flow capacity, 24, and arterial distensibility [39]. These changes increase the cardiovascular system's capacity to transport oxygen, thereby increasing $\mathrm{VO} 2 \max$ [40], and the higher VO2max [41] makes players capable of defending themselves in high-intensity training for a longer duration and recover faster in a soccer game situation.

The results of this study indicate that training with the long-term athlete development model does not affect academic achievement; thus, concerns over the effect of training, which gives negative impacts on it, can be eliminated. Some researchers said that the effect of exercise on academic achievement has a negative effect irrelevant to this study's results. High-volume exercise and academic demands may have resulted in excessive stress and low academic performance [18]. Malina et al. reported on their research that demands for sports specialisation (high training volume and many competitions) could result in chronic stress and fatigue [42]. These psychological problems and symptoms such as fatigue, depression, loss of motivation, and lack of concentration can result in cognitive decline and academic performance [43], [44]. Some cross-sectional research findings of the relationship between academic achievement and physical fitness have different results varying from relatively low. Still, the effect is positive [45], and the relationship is negative [20]. This study indicates that the sample has good aerobic endurance, but there is no effect on academic achievement. Still, several research findings state that physical fitness has a positive impact on academic achievement. For example, aerobic fitness in girls has a stronger relationship than boys on academic achievement at an elementary school level [46]. The body must avoid fatigue, so as not to show a decrease in one's performance. Learning activities deal with good health condition because they require physical and mental conditions. The brain works hard during the learning process, and it will drain energy quickly [47]. Aerobic fitness and body mass index are associated with reading and mathematics achievement, whereas strength and flexibility are not related to academic achievement, reading, and mathematics [19]. Based on some research results, it is recommended to promote physical activities in schools.

This study shows that exercise does not affect academic achievement; it can be understood if people notice that many factors influence it. Prospective athletes in a young training environment require more in-depth research on predictive factors. The dominant factors that influence the problem of the negative effects of sports training can be minimised. According to the stages, several interrelated factors that influence young athletes' academic achievement must be managed to achieve an athlete's career-academic achievement in mathematics and language influenced by intelligence quotient (IQ) [48]. Intelligence and personality have contributed to academic success [49]; other factors may include teachers as an essential learning resource, social capital, and parental involvement [50].

Collaboration between parents and teachers must develop to support children's academic achievement. A child's academic achievement influenced by other social factors such as low income, low level of mother's education, divorced parents' status, and lack of educational resources. Academic motivation provides a significant contribution or relationship to academic achievement. The sample participated in 12-month training with the long-term athlete development model. It reported that no one suffered from chronic injury, which means that young athletes' training model was following their abilities and interests. This research can be a reference or alternative for sports managers to select policies, models, or training strategies for young players. Identifying sports training's effect through organised activities on academic achievement can help sports administrators, teachers, and principals in the decision-making process.

Exercise must be done safely by the players. Pushing the children to do highly intensive exercise is not recommended, particularly taking a specialisation in one sport before adolescence. Several studies have suggested that sports training carried out with high ambition and motivation to win at a young age results in injury. Injuries such as tendinitis, apophysitis, and broken bones can occur due to an excessive exercise dose in children. Special components of young athletes who are in the growth stage can make children and adolescents experience traction apophysitis (osgood-schlatter disease, severe disease, medial epicondylitis), injury to the surface of the joints (osteochondritis dissecans), and/or injury to the immature spine (spondylolysis, spondylolisthesis, vertebral apophysitis) [12]. 
Optimal performance in sports and academic achievement in children is the expectation of all parents and teachers. To ensure that a child can achieve good academic performance is not easy, especially for children who have additional sports training activities with high volume and intensity in clubs or institutions that provide organised sports training. Young players not only undergo training but also enter exhausting competitions or matches. Concentration, planning, and implementation from one event to another take time, and missing school classes can be a problem. This research's advantage is that the treatment was carried out over a long time (12 months), with a sample of young athletes who took innovative training to develop physical abilities and academic achievement without obstacles. The monthly training program has well documented in 1 year. This study's main limitations are the different initial abilities of each athlete and the absence of the control group.

\section{Conclusions}

The conclusions of this study are: 1) the football training with the long term athlete development model in the age 10 and 12 groups has a significant effect on physical abilities, 2) the football training with the long term athlete development model in the age 10 and 12 groups has no significant effect on academic achievement, and 3) there is no significant difference in the football training with long-term athlete development model between the age 10 and 12 groups. For the recommendations, the long-term athlete development based-football training can be an alternative used by administrators, coaches, and athlete parents involved in the training and coaching. Achievement and performance during the match are prominent, but the welfare after the athlete career period is more important. Athletes' performance and success in learning and academic achievement must go hand in hand.

\section{Acknowledgments:}

The researcher would like to thank to all trainers, managers, and parents of Selabora Football School. Also, we would also like to thank for Universiti Malaysia Terengganu that has supported this research publication and one form of research collaboration among UMT, Universitas Sebelas Maret and Universitas Negeri Yogyakarta.

\section{Conflict of Interest:}

The authors state no conflict of interest.

\section{References:}

[1] Patel, R., Nevill, A., Smith, T., Cloak, R., \& Wyon, M., "The influence of birth quartile, maturation, anthropometry and physical performances on player retention: Observations from an elite football academy," Int. J. Sport. Sci. Coach., vol. 15, no. 2, pp. 121-134, Apr. 2020, doi: 10.1177/1747954120906507.

[2] Kavussanu, M., Stanger, N., \& Boardley, I. D., "The prosocial and antisocial behaviour in sport scale: Further evidence for construct validity and reliability," J. Sports Sci., vol. 31, no. 11, pp. 1208-1221, 2013, doi: 10.1080/02640414.2013.775473.

[3] Harwood, C., Spray, C. M., \& Keegan, R., Achievement goal theories in sport. 2008.

[4] Gilbert, W. D., Gilbert, J. N., \& Trudel, P., "Coaching Strategies for Youth Sports: Part 1: Athlete Behavior and Athlete Performance," J. Phys. Educ. Recreat. Danc., vol. 72, no. 4, pp. 29-33, Apr. 2001, doi: 10.1080/07303084.2001.10605736.

[5] Henry, I., "Athlete development, athlete rights and athlete welfare: A European Union perspective," Int. J. Hist. Sport, vol. 30, no. 4, pp. 356-373, Feb. 2013, doi: 10.1080/09523367.2013.765721.

[6] Lloyd, J., \& Wyatt, K., "The Healthy Lifestyles Programme (HeLP) — An Overview of and Recommendations Arising from the Conceptualisation and Development of an Innovative Approach to Promoting Healthy Lifestyles for Children and Their Families," Int. J. Environ. Res. Public Health, vol. 12, no. 1, pp. 1003-1019, 2015, doi: 10.3390/ijerph120101003.

[7] Holt, N. L., Neely, K. C., Slater, L. G., Camiré, M., Côté, J., Fraser-Thomas, J., ... \& Tamminen, K. A., "International Review of Sport and Exercise Psychology A grounded theory of positive youth development through sport based on results from a qualitative metastudy," Taylor Fr., vol. 10, no. 1, pp. 1-49, 2017, doi: 10.1080/1750984X.2016.1180704.

[8] Strachan, L., "Project SCORE! Coaches' perceptions of an online tool to promote positive youth development in sport," Exp. Find. Int. J. Sport. Sci. Coach., vol. 11, no. 1, pp. 108-115, Feb. 2016, doi: $10.1177 / 1747954115624827$.

[9] Hodge, K., \& Danish, S.J., "HDM-Couseling Psychologist Anti-Doping View project career transition View project," Sage, vol. 41, no. $8, \quad$ pp. 1125-1152, 2014, doi: 
$10.1177 / 0011000012462073$.

[10] Myer, G. D., Jayanthi, N., Difiori, J. P., Faigenbaum, A. D., Kiefer, A. W., Logerstedt, D., \& Micheli, L. J., "Sport Specialization, Part I: Does Early Sports Specialization Increase Negative Outcomes and Reduce the Opportunity for Success in Young Athletes?," Sports Health, vol. 7, no. 5, pp. 437-442, Sep. 2015, doi: 10.1177/1941738115598747.

[11] Balyi, I., "Long-Term Athlete Development: Trainability In Childhood And Adolescence Windows Of Opportunity, Optimal Trainability."

[12] American Academy of Pediatrics., "Intensive training and sports specialization in young athletes," Am Acad Pediatr., 2000, Accessed: Feb. 18, 2021. [Online]. Available: https://pediatrics.aappublications.org/content/ 106/1/154.short.

[13] Nashrullah, F.F., W. M. Radzi, S. Siswantoyo, and J. Saputra, "A study of sport-related legal provisions and regulations among elite student-athlete and staff in Yogyakarta public universities, Indonesia," $J$. Adv. Res. Dyn. Control Syst., vol. 12, no. 6, pp. 751-756, 2020.

[14] Bailey, R., Collins, D., Ford, P., MacNamara, Á., Toms, M., \& Pearce, G., "Participant development in sport: An academic review," Sport. Coach UK, vol. 4, pp. 1-134, 2010, Accessed: Feb. 18, 2021. [Online]. Available: https://www.researchgate.net/publication/242 743249.

[15] Sujarwo, S. Suharjana, H. A. Rachman, S. Siswantoyo, and J. Saputra, "Identifying the factor structure of physical education learning model and its effectiveness in improving the character values of students," J. Adv. Res. Dyn. Control Syst., vol. 12, no. 6, pp. 766775, 2020.

[16] Arkaev, L., \& Suchilin, NG., Gymnastics: how to create champions. 2004.

[17] Sukamti, E.R. Elumalai, G. Siswantoyo,. Saputra, J. Nugroho, W. \& Nugroho, A., "Technological innovation with visual and auditory stimulus: Testing the validity and reliability of smart WBRT 515-GM," J. Adv. Res. Dyn. Control Syst., vol. 12, no. 6, pp. 745-750, 2020.

[18] Richartz, A., Hoffmann, K., \& Bernardt, J., "Chronische belastungen und protektive ressourcen im kinderleistungssport. pädagogische diagnostik und unterstützungsansätze," BISp Jahrb., 2004.
[19] Castelli, D. M., Hillman, C. H., Buck, S. M., \& Erwin, H. E., "Physical Fitness and Academic Achievement in Third-and FifthGrade Students," J. Sport Exerc. Psychol., vol. 29, no. 2, pp. 239-252, 2007.

[20] Tremblay, M. S., Inman, J. W., \& Willms, J. D., "The Relationship Between Physical Activity, Self-Esteem, and Academic Achievement in 12-Year-Old Children," Human Kinetics Publishers, Inc, 2000.

[21] Chomitz, V. R., Slining, M. M., McGowan, R. J., Mitchell, S. E., Dawson, G. F., \& Hacker, K. A., "Is there a relationship between physical fitness and academic achievement? Positive results from public school children in the Northeastern United States," J. Sch. Health, vol. 79, no. 1, pp. 3037, Jan. 2009, doi: 10.1111/j.17461561.2008.00371.x.

[22] Ruiz-Ariza, A., Grao-Cruces, A., de Loureiro, N. E. M., \& Martinez-Lopez, E. J., "Influence of physical fitness on cognitive and academic performance in adolescents: A systematic review from 2005-2015," Int. Rev. Sport Exerc. Psychol., vol. 10, no. 1, pp. 108-133, 2017, doi: 10.1080/1750984X.2016.1184699.

[23] Bloom, G.A., \& Falcão, W., "Promoting Long Term Athlete Development in Cross Country Skiing Through Competency-Based Coach Education: A Qualitative Study Sport Psychology for Coaches: What do coaches think? View project," Sage, vol. 7, no. 2, pp. 301-316, Jun. 2012, doi: 10.1260/17479541.7.2.301.

[24] Bergeron, M. F., Mountjoy, M., Armstrong, N., Chia, M., Côté, J., Emery, C. A., ... \& Engebretsen, L., "International Olympic Committee consensus statement on youth athletic development," Br. J. Sports Med., vol. 49, no. 13, pp. 843-851, 2015, doi: 10.1136/bjsports-2015-094962.

[25] Impellizzeri, F. M., Marcora, S. M., Castagna, C., Reilly, T., Sassi, A., Iaia, F. M., \& Rampinini, E., "Physiological and Performance Effects of Generic versus Specific Aerobic Training in Soccer Players," Int. J. Sports Med., vol. 27, no. 6, pp. 483492, 2006, doi: 10.1055/s-2005-865839.

[26] Drenowatz, C., Steiner, R. P., Brandstetter, S., Klenk, J., Wabitsch, M., \& Steinacker, J. M., "Organized sports, overweight, and physical fitness in primary school children in Germany," J. obesit, 2013.

[27] Golle, K., Granacher, U., Hoffmann, M., Wick, D., \& Muehlbauer, T., 
"Humanwissenschaftliche Fakultät Effect of living area and sports club participation on physical fitness in children a 4 year longitudinal study Effect of living area and sports club participation on physical fitness in children: a 4 year longitudinal stud," $B M C$ Public Health, vol. 14, no. 1, pp. 1-8, May 2013, doi: 10.1186/1471-2458-14-499.

[28] Ammar, A., Trabelsi, K., Müller, P., Bouaziz, B., Boukhris, O., Glenn, J. M., ... \& Hökelmann, A., "The Effect of (Poly) phenolRich Interventions on Cognitive Functions and Neuroprotective Measures in Healthy Aging Adults: A Systematic Review and Meta-Analysis.," J. Clin. Med., vol. 9, no. 3, p. 835, Nov. 2020, doi: 10.1080/17461391.2016.1158321.

[29] Bellistri, G., Marzorati, M., Sodero, L., Sforza, C., Bradley, P. S., \& Porcelli, S., "Match running performance and physical capacity profiles of U8 and U10 soccer players," Sport Sci. Health, vol. 13, no. 2, pp. 273-280, Aug. 2017, doi: 10.1007/s11332016-0328-3.

[30] Malina, R. M., Ribeiro, B., Aroso, J., \& Cumming, S. P., "Characteristics of youth soccer players aged 13-15 years classified by skill level," Br. J. Sports Med., vol. 41, no. 5, pp. 290-295, 2007.

[31] Earp, J. E., Kraemer, W. J., Newton, R. U., Comstock, B. A., Fragala, M. S., DunnLewis, C., ... \& Maresh, C. M., "Lower-body muscle structure and its role in jump performance during squat, countermovement, and depth drop jumps," J. Strength Cond. Res., vol. 24, no. 3, pp. 722-729, 2010.

[32] Wisloeff, U. L. R. I. K., Helgerud, J. A. N., \& Hoff, J. A. N., "Strength and endurance of elite soccer players," Med. Sci. Sports Exerc., vol. 30, no. 3, pp. 462-467, 1998.

[33] Haugen, T. A., Tønnessen, E., Hisdal, J., \& Seiler, S., "The role and development of sprinting speed in soccer," Int. J. Sports Physiol. Perform., vol. 9, no. 3, pp. 432-441, 2014.

[34] Gabbett, T.J., \& Mulvey, M.J., "Time-Motion Analysis of Small-Sided Training Games and Competition in Elite Women Soccer Players," J. Strength Cond. Res., vol. 22, no. 2, pp. 543-552, 2008 ,

doi: 10.1519/JSC.0b013e3181635597.

[35] Elferink-Gemser, M. T., Visscher, C., Lemmink, K. A., \& Mulder, T., "Multidimensional performance characteristics and standard of performance in talented youth field hockey players: A longitudinal study," J. Sports Sci., vol. 25, no. 4, pp. 481-489, 2007.

[36] Bangsbo, J., Mohr, M., \& Krustrup, P., "Physical and metabolic demands of training and match-play in the elite football player," $J$. Sports Sci., vol. 24, no. 7, pp. 665-674, Jul. 2006, doi: $10.1080 / 02640410500482529$.

[37] Jovanovic, M., Sporis, G., Omrcen, D., \& Fiorentini, F., "Effects of speed, agility, quickness training method on power performance in elite soccer players," $J$. Strength Cond. Res., vol. 25, no. 5, pp. 12851292, 2011.

[38] Ekblom, B., "Effect of physical training in adolescent boys.," J. Appl. Physiol., vol. 27, no. 3, pp. 350-355, 1969.

[39] Rakobowchuk, M., Stuckey, M. I., Millar, P. J., Gurr, L., \& MacDonald, M. J., "Effect of acute sprint interval exercise on central and peripheral artery distensibility in young healthy males," Eur. J. Appl. Physiol., vol. 105 , no. 5, pp. 787-795, 2009, doi: 10.1007/s00421-008-0964-7.

[40] Bailey, S. J., Wilkerson, D. P., DiMenna, F. J., \& Jones, A. M., "Influence of repeated sprint training on pulmonary $\mathrm{O} 2$ uptake and muscle deoxygenation kinetics in humans," $J$. Appl. Physiol., vol. 106, no. 6, pp. 18751887, Jun. 2009, doi: 10.1152/japplphysiol.00144.2009.

[41] Helgerud, J., Engen, L. C., Wisloff, U., \& Hoff, J., "Aerobic endurance training improves soccer performance," Med. Sci. Sports Exerc., vol. 33, no. 11, p. 1925, 2001.

[42] Malina, R. M., "Early sport specialization: roots, effectiveness, risks," Curr. Sports Med. Rep., vol. 9, no. 6, pp. 364-371, 2010.

[43] Kusurkar, R. A., Ten Cate, T. J., Vos, C. M. P., Westers, P., \& Croiset, G., "How motivation affects academic performance: A structural equation modelling analysis," $A d v$. Heal. Sci. Educ., vol. 18, no. 1, pp. 57-69, Mar. 2013, doi: 10.1007/s10459-012-9354-3.

[44] Wagner, S., Müller, C., Helmreich, I., Huss, M., \& Tadić, A., "A meta-analysis of cognitive functions in children and adolescents with major depressive disorder," European Child and Adolescent Psychiatry, vol. 24, no. 1. Dr. Dietrich Steinkopff Verlag GmbH and Co. KG, pp. 5-19, Jan. 2015, doi: 10.1007/s00787-014-0559-2.

[45] Sallis, J. F., McKenzie, T. L., Kolody, B., Lewis, M., Marshall, S., \& Rosengard, P., "Effects of health-related physical education 
on academic achievement: Project spark," Res. Q. Exerc. Sport, vol. 70, no. 2, pp. 127134, Jun. 1999, doi: 10.1080/02701367.1999.10608030.

[46] Eveland-Sayers, B.M., Fuller, D.K., Morgan, D., \& Farley, R.S., "Physical fitness and academic achievement in elementary school children," J. Phys. Act. Health, vol. 6, no. 1, pp. 99-104, 2009, Accessed: Feb. 18, 2021. [Online].

Available: https://journals.humankinetics.com/view/jour nals/jpah/6/1/article-p99.xml.

[47] Kriswanto, E. S., Setijono, H., \& Mintarto, E., "The effect of cardiorespiratory fitness and fatigue level on learning ability of movement coordination," Cakrawala Pendidik., vol. 38, no. 2, pp. 320-329, 2019, doi: 10.21831/cp.v38i2.24565.

[48] Mayes, S. D., Calhoun, S. L., Bixler, E. O., \& Zimmerman, D. N., "IQ and neuropsychological predictors of academic achievement," Learn. Individ. Differ., vol. 19, no. 2, pp. 238-241, 2019.

[49] Laidra, K., Pullmann, H., \& Allik, J., "Personality and intelligence as predictors of academic achievement: A cross-sectional study from elementary to secondary school," Pers. Individ. Dif., vol. 42, no. 3, pp. 441451, 2007, doi: 10.1016/j.paid.2006.08.001.

[50] Schlee, B. M., Mullis, A. K., \& Shriner, M., "Parents social and resource capital: Predictors of academic achievement during early childhood," Child. Youth Serv. Rev., vol. 31, no. 2, pp. 227-234, 2009.

\section{Contribution of individual authors to the creation of a scientific article (ghostwriting policy)}

Sulistiono writing - original draft, editing and investigation.

Sugiyanto writing - original draft, investigation, editing and supervision.

Agus Kristiyanto writing - original draft, investigation, editing and supervision.

Sapta Kunta Purnama writing - original draft, investigation, editing and supervision.

Jumadil Saputra writing - methodology, review, editing, investigation, and data analysis.

Siswantoyo writing - methodology, review, editing and supervision.

Nawan Primasoni writing - methodology, review, and editing.
Sources of funding for research presented in a scientific article or scientific article itself

This research publication is funded by Universitas Negeri Yogyakarta, Sleman, Daerah Istimewa Yogyakarta 55281, INDONESIA.

\section{Creative Commons Attribution License 4.0} (Attribution 4.0 International, CC BY 4.0)

This article is published under the terms of the Creative Commons Attribution License 4.0 https://creativecommons.org/licenses/by/4.0/deed.en US 